\title{
Nutrition education curriculum for the Adolescent Girls Empowerment Program (AGEP)
}

Population Council

Follow this and additional works at: https://knowledgecommons.popcouncil.org/departments_sbsr-pgy

Part of the Family, Life Course, and Society Commons, Gender Equity in Education Commons, and the International and Community Nutrition Commons

How does access to this work benefit you? Let us know!

\section{Recommended Citation}

Population Council. 2014. "Nutrition education curriculum for the Adolescent Girls Empowerment Program (AGEP)." Lusaka: Population Council. 


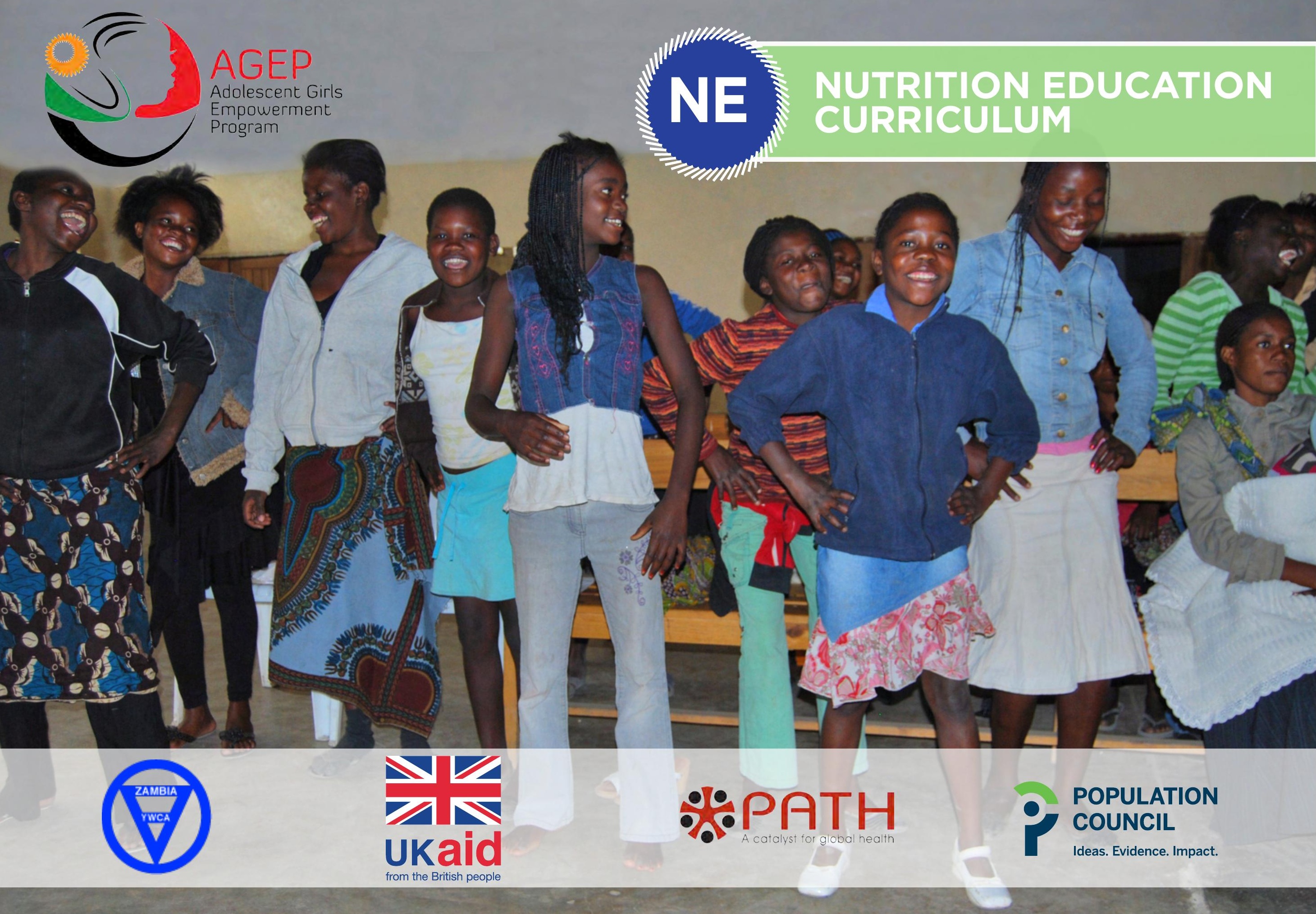




\section{POPULATION \\ COUNCIL \\ Ideas. Evidence. Impact.}

The Population Council confronts critical health and development issues-from stopping the spread of HIV to improving reproductive health and ensuring that young people lead full and productive lives. Through biomedical, social science, and public health research in 50 countries, we work with our partners to deliver solutions that lead to more effective policies, programs, and technologies that improve lives around the world. Established in 1952 and headquartered in New York, the Council is a nongovernmental, nonprofit organization governed by an international board of trustees.

Population Council

One Dag Hammarskjold Plaza

New York, NY 10017

Tel: 212-339-0500

Fax: 212-775-6092

www.popcouncil.org

Email: publications@popcouncil.org

Email: agep@popcouncil.org

Population Council - Zambia

Plot 3670 No. 4 Mwaleshi Road

Olympia Park, Lusaka

P/Bag RW 319X, Lusaka 10101, Zambia

Lusaka, Zambia 10101

Tel: +260 211295925

(c) 2014 The Population Council, Inc.

Written permission from the Population Council is required for any reproduction or distribution of more than fifty (50) copies per year, any electronic reproduction or any major change in content.

For inquiries regarding rights and permission, please contact publications@popcouncil.org.

Sections of this book may be reproduced, translated or adapted with minor changes to meet local needs, provided they are distributed free or at cost and not for profit and provided that any changes maintain the integrity of the book. Please inform the Population Council of plans to translate these materials into another language and provide one (1) copy of the publication.

This curriculum has been adapted from several sources, which are listed in the references section.

Please include the following statements on all section reproductions:

Reprinted from Population Council: Nutrition Education Curriculum for the Adolescent Girls Empowerment

Program (AGEP) 


\section{NE TABLE OF CONTENTS}

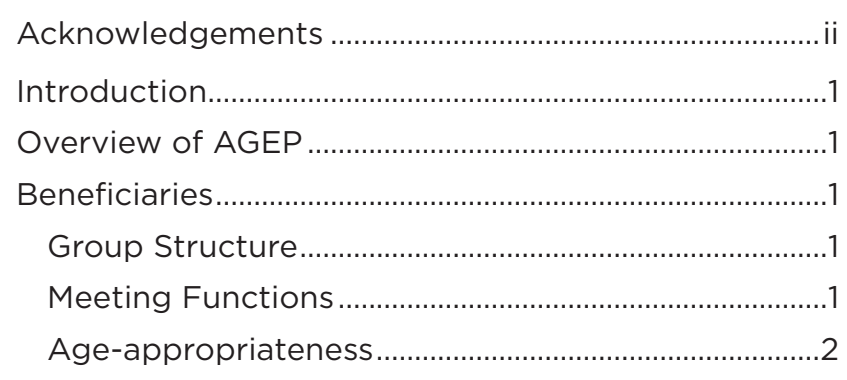

\section{SECTION 1: NUTRITION NEEDS FOR}

\section{ADOLESCENT GIRLS .................................................... 4}

Introduction............................................................................

Icebreaker: In the River...On the Bank ..............................5

ACTIVITY 1: Building Blocks of Nutrition ........................ 6

ACTIVITY 2: Racing the Food Pyramid .......................... 8

ACTIVITY 3: Helpers for the Staple Food -

Go, Grow and Glow Foods

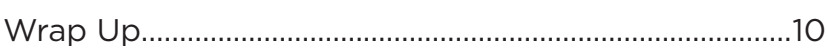

\section{SECTION 2: THE ROLE OF FOOD IN THE BODY .....11}

Icebreaker: Fruit Salad .......................................................... 12

Review ................................................................................. 12

ACTIVITY 1: From the Market or Garden

to the Kitchen .................................................................... 13

ACTIVITY 2: Keeping Our Bodies and Minds

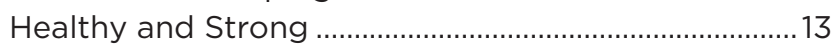

Wrap Up. .14

\section{SECTION 3: ANAEMIA IN}

ADOLESCENT GIRLS ............................................. 15

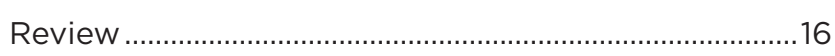

Icebreaker: To Whom To.......................................................16

ACTIVITY 1: Why Am I So Tired?..................................... 17

CASE SCENARIO: Why Am I So Tired? ........................... 18

ACTIVITY 2: What Should I Eat? ......................................19

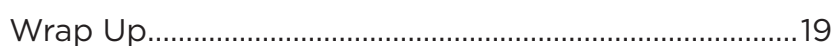

\section{SECTION 4: NUTRITION FOR}

PREGNANT ADOLESCENTS.

20

Icebreaker: The Ship Is Sinking …..................................... 21

Review ................................................................................. 21

ACTIVITY 1: Food and Nutrient Needs

in Pregnancy ....................................................................... 22

ACTIVITY 2: Common Eating Behaviours in

Pregnant Adolescents ........................................................ 23

Wrap Up......

.23

\section{SECTION 5: INFANT FEEDING FROM BIRTH} THROUGH SIX MONTHS.

\section{4}

Review.....

.... 25

ACTIVITY 1: Breastfeeding................................................. 25

ACTIVITY 2: Early Initiation of Breastfeeding .............26

ACTIVITY 3: Exclusive Breastfeeding until

Six Months of Age.

Wrap Up.

29

\section{SECTION 6: YOUNG CHILD FEEDING}

AND GROWTH MONITORING.

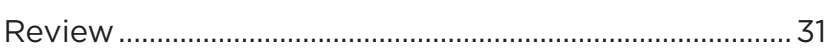

ACTIVITY 1: Feeding the Baby After

Six Months of Age.

ACTIVITY 2: Growth Monitoring:

Children's Under-Five Clinic Card.................................... 34

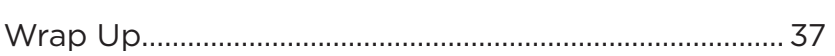

REFERENCES 


\section{ACKNOWLEDGMENTS}

This curriculum was developed as part of the Adolescent Girls Empowerment Program, funded by a grant from the UK Department of International Development. The overall goal of the program is to help vulnerable adolescent girls in Zambia build their social, health and economic assets. The project is led by the Population Council, in partnership with the Young Women's Christian Association of Zambia (YWCA Zambia), the National Savings and Credit Bank (NatSave), Making Cents International, and the Government of the Republic of Zambia.

The nutrition curriculum was adapted by Albertha Nyaku, Amelia Kinter, Dorothy Nthani, and Tina Kaonga from PATH, and Bwalya Mushiki, Karen Austrian, Natalie Jackson Hachonda, Nambula Kachumi, and Paul Hewett from Population Council.

We would like to acknowledge several organizations whose materials have been adapted or used in this curriculum including: Center for Leadership, Education and Training in Maternal and Child Nutrition, Division of Epidemiology and Community Health, School of Public Health, University of Minnesota; Ministry of Health (MOH), Republic of Zambia; Population Reference Bureau (PRB); and World Health Organization (WHO). A citation for the materials used from these organizations can be found in the footnotes at the beginning of each session and a complete reference is located in the "References" section at the end of this document. 
Zambian girls are faced with social isolation, economic vulnerability, and lack of appropriate health information and services-factors that prevent a healthy transition from girlhood into womanhood. They are faced with high rates of genderbased violence and unsafe sex-increasing their risk for unwanted pregnancy, HIV infection, and school dropout. This leads to a lack of economic resources and income-generating options, and a general lack of agency in shaping their lives.

The root cause of these vulnerabilities is largely determined by girls' weak social, health, and economic assets.

The Adolescent Girls Empowerment Program (AGEP) aims to build these assets as an interconnected approach towards mitigating girls' vulnerabilities. The Population Council and partners have piloted and implemented a social, health, and economic asset-building program for vulnerable adolescent girls in Zambia. Girls joined groups of 25-30 girls, which meet once a week under the guidance of a female mentor. In weekly group meetings, girls are provided with training on health and life skills and financial education with half of the girls receiving training on nutrition.* Through the group meetings, girls are also given the opportunity to interact to build strong relationships with other girls in their community.

\section{OVERVIEW OF AGEP}

The overall goal of AGEP is to facilitate the building of social, health, and economic assets in a safe and fun learning environment. Participants are equipped with life skills and knowledge to help maintain happy and healthy lifestyles, and be empowered with the confidence to assert their rights and protect themselves from harm and threats.

The 'safe spaces' component is at the core of AGEP. The girls groups, to which each girl belongs, are meant to provide a safe and supportive learning environment. Regular and reliable girls' group meetings, under the guidance of a female mentor from the same community, are critical in building social assets for vulnerable girls-including friendships, self-esteem, trusting relationships with adults, social support, etc.

\section{BENEFICIARIES}

AGEP participants are girls who are 10-19-years-old from vulnerable backgrounds. While some girls may be in school, the program is not meant to target in-school girls, nor are the groups meant to meet in school or be seen as school clubs. Special recruitment is done to ensure that girls who are, or at high risk of soon becoming, out-of-school, young mothers, married, domestic workers, disabled, or other profiles of vulnerablility are included

\section{Group structure}

Each group meets once a week in a time and location that is deemed appropriate by the girls, the community, and the mentor. Groups meet in various locations throughout the community and the meetings last between 1-2 hours.

\section{Meeting functions}

The meetings serve two functions. The first is for the mentor to facilitate a short training session. The training content over the course of the year varies from

sexual and reproductive health and life skills to financial education (see separate Financial Education curriculum), and half of the girls will receive nutrition training. These sessions should be engaging, interactive, and make use of best practice youth learning principles - that is games, small group work, etc.

The second function is for the meetings to provide a space and opportunity for girls to regularly interact with each other. During meeting times, they can share updates about their weeks, address any concerns they may have, laugh, sing, dance, express themselves, and in general, have fun. As cultivating this sort of environment is a primary aim of weekly girls group meetings, it is important that these groups not be run like a classroom. Mentors will have to ensure that during each meeting, girls have ample time for conversation and interaction, and should encourage an informal learning environment at all times. 


\section{Age appropriateness}

This program was designed for girls from 10 to 19 years of age. However, some of the material contained in the curriculum may not be suitable for participants at the younger end of this age spectrum. Though participants will attend sessions with other participants closer to their age (groups of 10-14 year-olds and 15-19 year-olds formed in the first session), topics or activities that are more appropriate for younger adolescents (ages 10-14) or older adolescents (ages 15-19) are specified throughout the curriculum. They are marked with the following signs:

\section{0-14-year-olds} only

\section{5-19-year-olds} only
The final decision on how to present the material is at the discretion of the mentor.

For more information about the Adolescent Girls Empowerment Program, please visit: http://www.popcouncil.org/projects/353_ZambiaAGEP.asp. The Health and Life Skills and Financial Education curricula can also be accessed at this webpage.

For any inquiries, please contact: agep@popcouncil.org. 


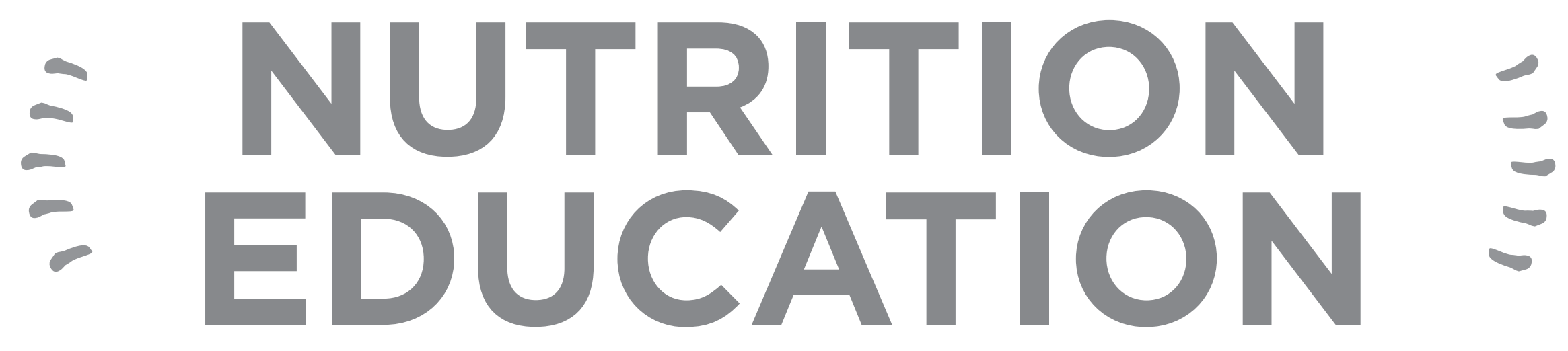




\section{Nutrition Needs for Adolescent Girls*}

This session discusses the importance of adolescent girl's nutrition, identifies suitable foods and provides guidelines for healthy food choices FACILITATORS' NOTES: Adolescents need a variety of foods in their diet in order to grow well and stay healthy. This session outlines basic food groups and explains the importance of eating foods from all groups at most meals. The girls will learn how to make healthy food choices.

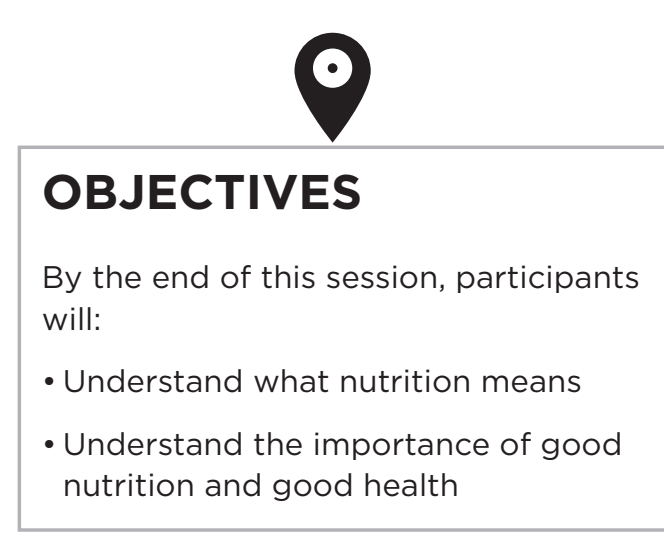

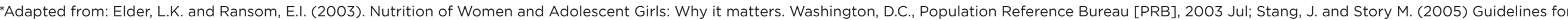

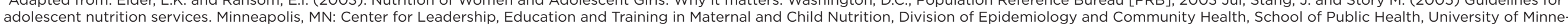
sota; Whitney, E and Rolfes, S. R. (2005) Understanding Nutrition, 10th Edition. Thomson Wadsworth. 


\section{Intraduction}

(5 MINUTES)

Say:

Welcome to the learning session on the foods we eat and what we get from them. What we get from food is called nutrition.

\section{Explain:}

$\bigcirc$ We are meeting together in our Safe Spaces to support each other, and learn about how to make good decisions in our lives. We are now going to learn about food and nutrition and how to make healthy food choices. This is because food and nutrition are important to our health. If we have good nutrition we can grow strong and stay healthy for the rest of our lives.

\section{Ask:}

5 What did you eat for breakfast (or lunch)?

(

Wait for a few replies

Ask:

S Why did you eat........? (Insert what the girls mentioned)

$\otimes$

Wait for a few replies

\section{Say:}

What we eat affects every part of our lives. It can make us feel good or sick, it can help us grow, and it can give us energy to help keep us healthy. To start talking about food and nutrition let us begin to move around and use some energy to get us excited.

\section{Icelreaker: In the River... On the Bank}

\section{(5 MINUTES)}

Say:

S We are going to play a game called "In the river...On the Bank". We will all get in a circle. When I say "in the river" everyone is going to jump one step forward, and when I say "on the bank" everyone is going to jump one step backwards. If you jump the wrong direction or make a move that signifies intent to move, you are out of the game. We will first do a practice round and then we will play the game.

Action:

If Conduct a practice round shouting "in the river" or "on the bank" at least once. Then announce that the game has started.

Once the game has started shout "in the river...on the bank" instruction with increased speed between each action; as the girls jump for each call. You can repeat the instruction "in the river" or "on the bank" in rapid succession. The girls that perform a different action or make a move showing intent to make a wrong action fall out of the game.

End the game when only a few girls are remaining in the circle and you are sure that everyone is alert and ready to continue. 


\section{activity 1}

\section{BUILDING BLOCKS OF NUTRITION}

\section{(3O MINUTES)}

\section{Explain}

In this activity we are going to learn about the role of food in the body.

Say:

What do you think nutrition means?

\section{Action:}

Allow the girls to use the local word for nutrition, if there is one, i.e. in Bemba "ukulya bwino". Listen to their different answers, but do not give approval or denial. There are no wrong answers, just listen. This will allow you to have a better understanding of the girls' knowledge base.

Say:

What we eat or drink is broken down into tiny pieces called nutrients (food elements) that the body needs. The nutrients give our bodies' energy and other benefits so that we can walk, run, work, play, grow, and fight sickness.

\section{Explain:}

To have good nutrition and remain healthy we must eat a variety of foods each day.

\footnotetext{
Action:

ic

Place the plastic building block creation in front of the girls.
}

Ask:

What do these building blocks have to do with food?

(7) Wait for the girls to reply. It is not expected that the girls would know the answer. The question should stimulate their interest and involve them in the discussions.

Ask:

What would happen if one piece is taken out of the block creation? Or if all the pieces of one colour - yellow, blue green or red were removed?

Action:

Demonstrate by removing one block and have the wall fall apart.

Say:

The body is made up of many smaller pieces and each of them has a specific role to play in the body

Explain:

$\int$ Like building blocks that are used to make a wall, each food group comprises foods containing different nutrients called vitamins, minerals, proteins and carbohydrates that the body needs to stay strong and healthy. The body uses these nutrients to build our muscles, bones, blood, hair, nails, cells, tissues and many more parts and keep them strong and healthy.

\section{Say}

These building blocks (nutrients) come in different colours and each colour has a special job in the wall. In the same way foods are grouped into six different food groups:

1. cereals and tubers; 2 . fruits; 3 . vegetables; 4. meat, poultry, dry beans, eggs and nuts;

5. milk, yogurt, cheese; 6 . fats, oils and sweets. These foods can be seen as arranged in the food pyramid.

Action:

75 Show the food pyramid to the girls. Note: Use the food pyramid shown on page 7 if you do not have a larger one to display.

\section{Explain:}

The base of the food pyramid is wider so we should eat more of those food servings in that food group. As the food pyramid draws to the top, it gets smaller suggesting eating smaller quantities of food from these food groups. At the top of the pyramid are foods that need to be eaten less. To meet the nutrient needs essential for good health, you need to eat a variety of food from each of the different food groups daily. It is important to enjoy a variety of foods within each food group because different foods have different key nutrients. It is, however, not necessary to eat all the food from each food group at every meal. In fact, you only need to eat some of the foods such as eggs, meat and chicken a few times a week. 


\section{Recommended Daily Food Pyramid}

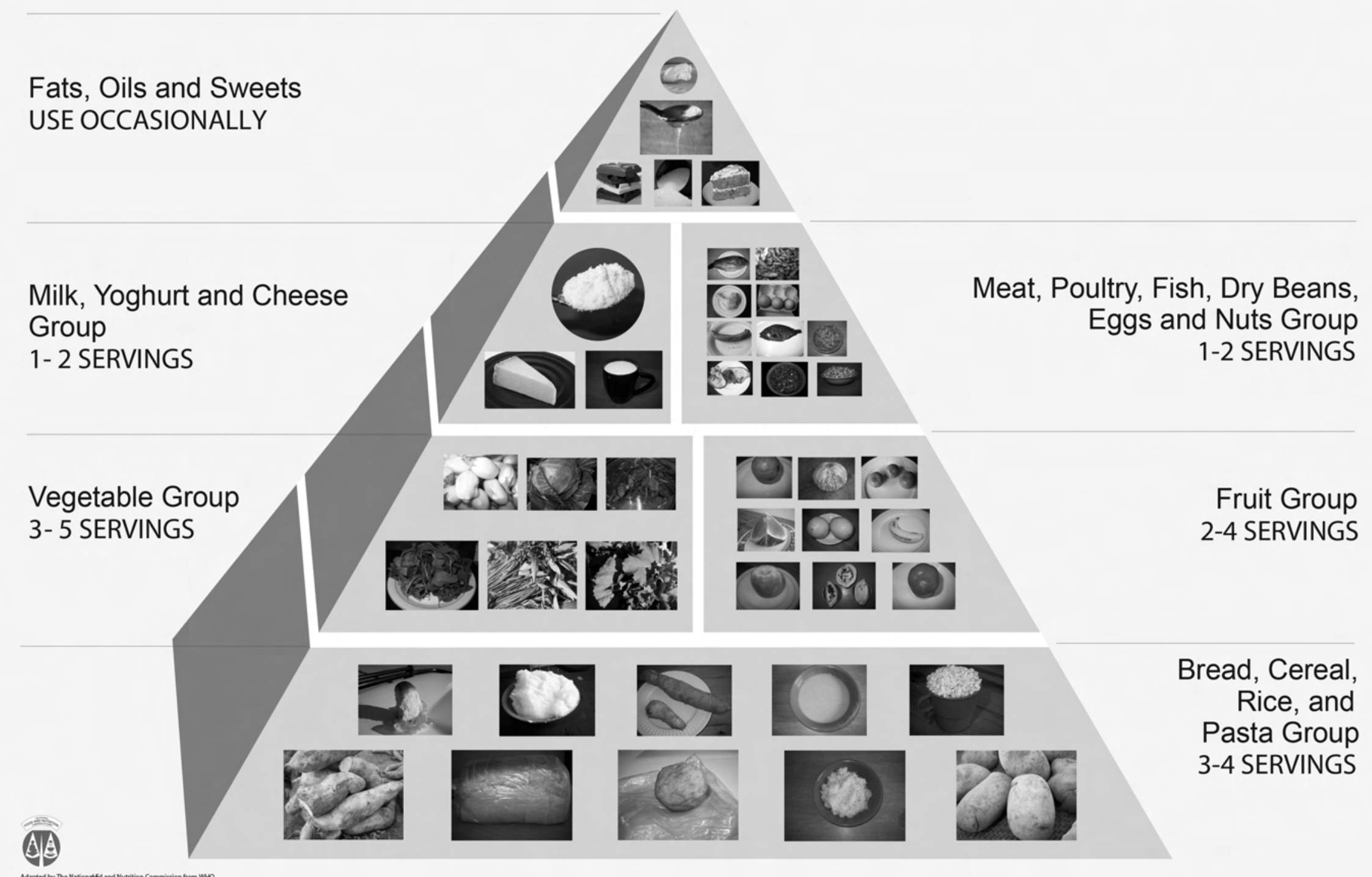




\section{activity 2}

\section{RACING THE FOOD PYRAMID}

(3O MINUTES)

\section{Explain:}

In this activity we are going to build the food pyramid using a relay race.

\section{Action:}

Place food pyramid grids for teams A and B on the floor or wall where available on the furthest side of the meeting space. Divide the girls into two relay race teams $A$ and $B$. Draw start lines and ask the girls to stand behind the drawn lines. Tell the girls that each team will work with a grocery bag of selected food picture cards. Give the teams instructions about how the race will be played.

\section{Say:}

When it is your turn grab a food picture from the grocery bag and run to the far side of the play area. Put the picture card in the food group where it belongs in the food pyramid. You will then run back to your team and tag the next team member to pick a food picture card from the grocery bag and run to place it on the food pyramid. Repeat these actions in your teams until all the food picture cards in the grocery bag are placed on the pyramid. The team that finishes first with most or all the food picture cards placed correctly wins.

\section{Action:}

Stand in a position where you will be able to see what is happening in both teams and be able to stop girls from cheating. Give the girls the start signal. Make sure that the girls take turns and participate nicely.

Ask all the girls to come to one of the food pyramids and review the outcomes. Hold a discussion by going through all the food picture cards in each food group in turn.

Ask the girls if each food picture card has been placed in the right place and provide a brief explanation to support the answer. For the food picture cards that have been misplaced, ask where they should be placed, again giving reasons for the change.

When you finish commenting on one food pyramid, ask the girls to move to the other pyramid and repeat the process.

Determine and congratulate the winning team based on who had the most food picture cards placed correctly.

When the discussion is complete, have the girls sit down in readiness for the next activity. 


\section{activity 3}

\section{HELPERS FOR STAPLE FOOD - GO, GROW AND GLOW FOODS}

\section{(25 MINUTES)}

\section{Explain:}

$\Omega$ In this activity we are going to learn another way of making balanced meals with the right kinds of food eaten together.

\section{Action:}

F Collect the cards labeled Staple (Main food), Go, Grow and Glow. Use these cards to explain the other way of constructing meals with the right kinds of foods eaten together

\section{Explain:}

We shall now talk about meal planning using the staple, go, grow and glow guiding principle. This idea emphasizes the importance of getting enough staple foods at the centre and placing the three (3) helper foods around it.

\footnotetext{
Action:

Demonstrate how a balanced meal is achieved using the labeled cards.
}

STAPLE foods include cereals and grains (wheat, maize, rice, millet and sorghum), starchy roots (potatoes, cassava) and starchy fruits (bananas and plantains). These foods provide the body with energy.

GO foods include oils, butter, nuts, oils seeds, bacon, fatty meat and coconut, sugar, honey, molasses and sugar cane. These foods help the body to have energy to run, play, work, think and generally to keep the body in good working condition.

GROW foods (high protein foods): These include legumes (peas, beans, and soya beans), oil seeds (soya beans, groundnuts) and food that comes from animals (meat, milk, chicken, eggs, fish and insects). When eaten with staple foods, these foods help the body to grow well and stay healthy.

GLOW foods (rich in vitamins and minerals): These foods include dark green leafy vegetables (DGLV) such as chibwabwa, spinach, sweet potato leaves, rape, bondwe, and kanunkha; tomatoes and carrots; and fruits like mangoes, oranges, and guavas. Also included are chicken, eggs, meat, milk and fish. All these foods are excellent sources of vitamins and important elements that are used by the body. Glow foods keep us healthy and help the hair, eyes and skin to look shiny or to "glow".
Ask:

5 Why is it so important to eat different kinds of foods from each of the food groups? What do you think might happen to a girl who eats only two kinds of food at every meal (nshima and beans or nshima and chibwabwa)?

( Wait for a few replies. Prompt the quiet girls to say something too.

\section{Explain:}

It is important to enjoy foods from each of the food groups because different foods provide us with different amounts of key nutrients. It is not necessary to eat from each food group at EVERY meal but make sure that you eat from ALL food groups by the end of the day.

Ask:

How can you be sure that you are getting the nutrients needed?

Explain:

5 If we eat a variety of foods from all the food groups, we will get a mixture of nutrients required by the body for growth and strength. It is important to eat a variety of foods from each of the food groups in order to GO, GROW and GLOW! 


\section{Wrap $U_{\text {r }}$}

(10 MINUTES)

\section{Anton}

Ask the girls to summarize what they have learnt. Fill in any key points missed.

Key Message: The food we eat is broken down into tiny pieces called nutrients used for body building. The nutrients give our bodies energy and other benefits so that we can walk, run, work, play, grow, and fight sickness.

Ask for final questions or comments. Remind the girls where and when the next meeting will take place and the topics to be discussed.

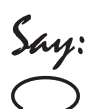

We have come to the end of today's session. Thank you all for coming. I hope today's activities have excited you about the foods you will be choosing to eat. 


\section{2) The Role of Food in the Body*}

This session discusses the role of food in achieving a healthy mind and body.

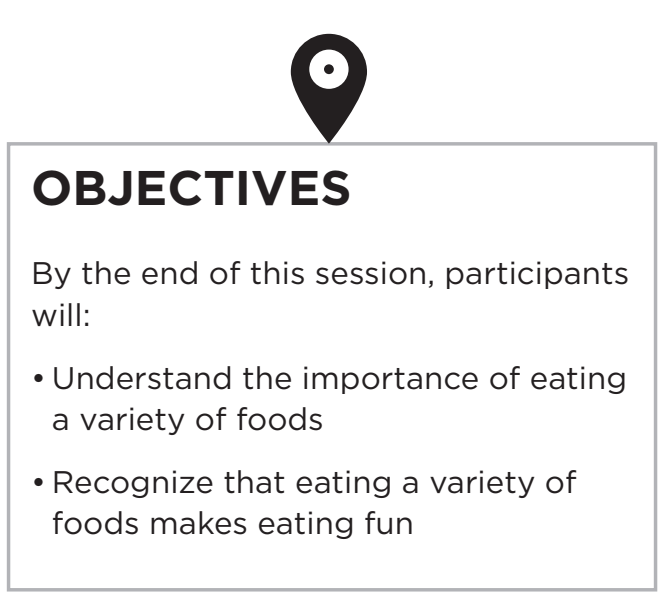

\begin{tabular}{l} 
MATERIALS \\
- Flipchart (more than 15 \\
sheets of paper) \\
- Talking Stick (a cane, \\
stick, or rolled up piece \\
of paper) \\
- Assorted Markers \\
- Sticky stuff (or masking \\
tape) \\
\hline
\end{tabular}

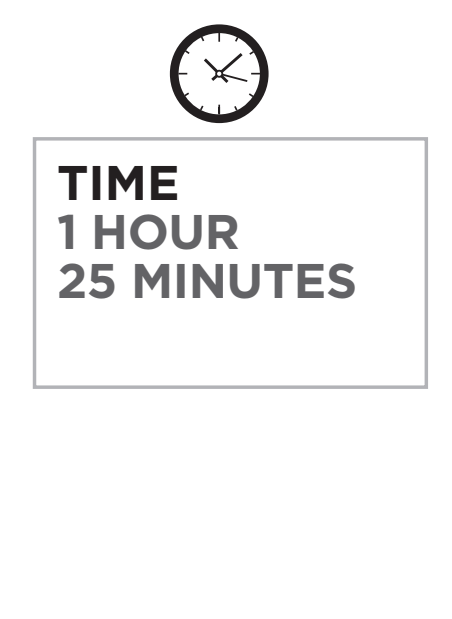

ACTIVITIES
1. Icebreaker (5 minutes)
2. Review (10 minutes)
3. From the Market or Garden
to the Kitchen (30 Minutes)
4. Keeping Our Bodies and
Minds Healthy and Strong
(30 Minutes)
5. Wrap Up (10 Minutes)

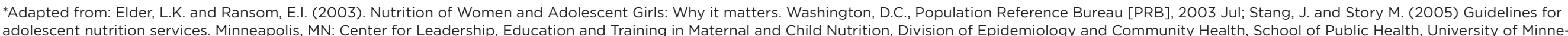
adolescent nutrition services. Minneapolis, MN: Center for Leadership, Education and Training in Mater 


\section{leclereaker: Frint Salad}

\section{(5 MINUTES)}

\section{Explain:}

Welcome to the second session on nutrition for adolescent girls. We shall start the session by engaging in an icebreaker.

\section{Action:}

Assign the girls into a kind of fruit (Banana, Pineapple, Watermelon, Orange Mango, Guava, Apple, Pear, etc.). The number of fruits used will depend on the number of girls in attendance. Ask the girls to sit or stand in a circle with one girl standing in the middle.

\section{Explain:}

5 Each girl will play the role of a fruit. Ask all the girls to stand in a circle and only one stands in the center of the circle. The girl in the middle mentions a fruit name and the girls who are that fruit must quickly move to an open spot in the circle before the girl in the middle occupies their space. The girl left standing will announce the next fruit. If the girl in the center says "Fruit Salad" everyone must change positions.

\section{Action:}

Play the game for 3 minutes to allow the girls' time to get energized for the session.

\section{Review}

(10 MINUTES)

Action:

Give one (1) food picture card to each of the girls.

Write names of food groups (or draw if there are any girls who are not able to read) [1. cereals and tubers; 2 . meat, poultry, dry beans, eggs and nuts; 3 . fruits; 4 . vegetables; 5 . milk, yogurt, cheese; 6 . fats, oils and sweets] on 6 separate blank VIPP cards and place those in selected places around the room or safe space face down.

Say:

Let's see how much you remember about which foods belong to each of the food groups. Uncover and point out the location of each food group label posted around the room.

Action:

In Uncover and point out the location of each food group label posted around the room.

\section{Explain:}

$S$ Look at your food picture cards and decide what food group it belongs to. Stick the food picture card on the food group. If you are not sure you may ask another girl for help.

Action:

Go around to each food card and verify if the food picture cards placed by the girls are in the correct place. If you find a vegetable in the meat section, ask the group if it is in the right place. Ask where it should be and move it to the right place. Start a brief discussion while asking girls about the key points covered in the last session.

Optional: Throw a ball of paper around to encourage participation. Fill in any key points missed. 


\section{activity 1}

\section{FROM THE MARKET OR GARDEN TO THE KITCHEN}

(30 MINUTES)

\section{Explain:}

5 We will now learn about how to choose and combine foods for healthy meal planning.

\section{Action:}

Divide the girls into smaller groups. Provide each group with a deck of selected food picture cards.

Say:

Take an imaginary trip to the market or garden to buy or harvest food that you will use to prepare lunch (or supper as the case may be). Choose from the deck of food picture cards food you will buy or harvest. When you are done with your trip to the market or garden, each group will present the meals they planned to prepare and will show the different food picture cards to be used in that meal. The groups will also explain why you have chosen each kind of food.

\section{Action:}

Hhen one group presents, ask the other girls what they think of the food chosen and the meal planned by that group.

Make corrections where need be and end by making concluding remarks.

\section{activity 2}

\section{KEEPING OUR BODIES AND MINDS HEALTHY AND STRONG}

(30 MINUTES)

\section{Explain:}

$\bigcirc$ In this activity we will learn about foods that will help us to keep our bodies and minds healthy and strong.

Say:

Good eating habits can help us keep our bodies and minds healthy and strong. Other ways healthy eating can help us include keeping us alert and strong by helping our bodies fight sickness and disease.

\section{Explain:}

$\bigcirc$ There are lots of healthy foods, unhealthy foods, and foods where we are not sure if they are healthy or unhealthy.

\section{Action}

Take these three signs: healthy, unhealthy, not sure and stick them on the wall or place on the ground. Place food picture cards in a grocery bag.

Begin a discussion about the different kinds of food. Hold up a picture of any food from the grocery bag and ask the girls to tell you where it belongs. For example, if you hold up an avocado it would go to the healthy label. If you hold up Fanta or Coke, cake, or chocolate it would go to the unhealthy label. If you held up chikanda it might go in the not sure" label since it has both healthy and unhealthy qualities. Allow discussion if the girls don't agree on where the food should go.

Continue to hold up one food picture card at a time and ask the girls where it should be placed. Continue this process until you have a number of food picture cards under each of the labels.

Explain:

Different foods affect our bodies differently. If you put fresh fruits and vegetables, whole grains and nuts, or food filled with lots of vitamins and nutrients into your body, your body will grow and feel strong. If you eat more food that is not healthy as compared to food that is healthy your body will not like it and you will have less energy, feel less well and get sick easier.

Ask:

What do you make of the results of this activity? Are the foods placed under the "healthy" food label found in our community?

(x) Wait for a few replies

\section{Explain:}

As you can see there are many healthy foods in our communities. This means that it is possible to eat healthy food and live a healthy life. All we need to do is stop a while and think about what we eat to make the right food choices. 


\section{Wrap U⿻}

(10 MINUTES)

\section{Artan}

Ask the girls to summarize what they have learnt. Fill in any key points missed.

Key Message: Our bodies need healthy foods to have energy, to be strong, alert and protected us from illnesses. Good nutrition is achieved by eating different kinds of foods in the right amounts.

Ask for final questions or comments.

\section{Say:}

We have come to the end of today's session. Thank you all for coming. We shall continue with another topic on nutrition for adolescent girls in our next meeting.

Remind the girls where and when the next meeting will take place. 


\section{3) Anaemia in Adolescent Girls*}

This session will introduce the girls to the signs, causes and dangers of anaemia.

FACILITATORS' NOTES: Adolescents are at a great risk of anaemia because they grow quickly, and they do not eat enough food with an important mineral called iron to keep up with their quick pace of growth. Adolescent girls who start their menses need more iron because they are at risk due to blood loss during menstrual periods. In some cases pregnancy can also lead to anaemia. Girls who do not eat sufficiently or lose a lot of weight due to illness are also at risk of not eating enough iron.

OBJECTIVES
By the end of this session, participants
will:
- Define anaemia
- Identify the signs and symptoms of
anaemia
- Discuss the dangers of getting
anaemia
- Identify the food sources that can
prevent anaemia
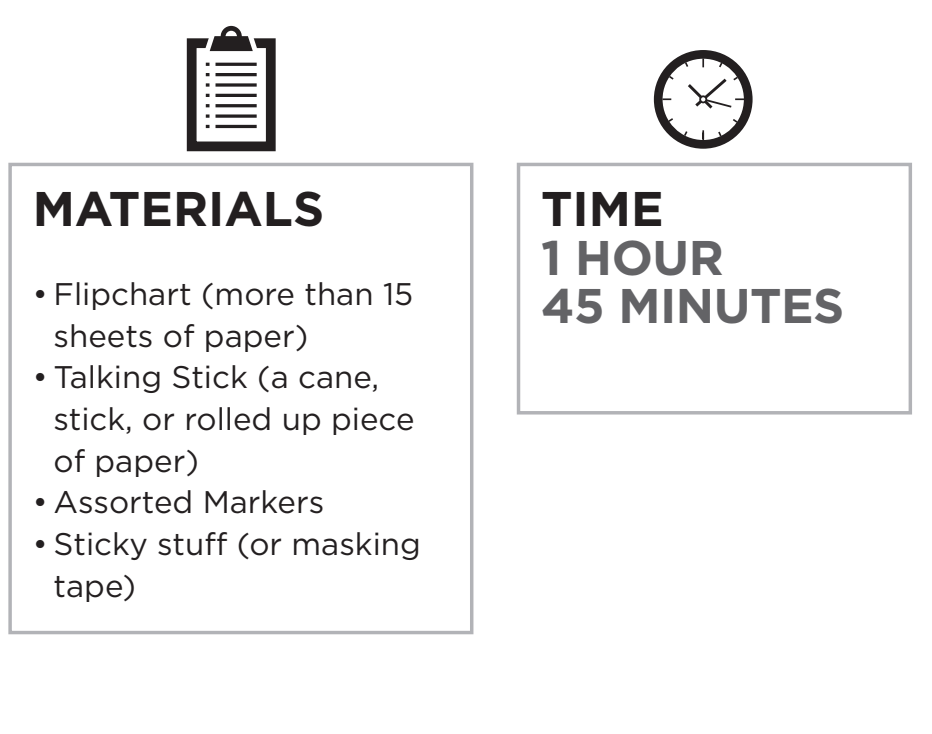

ACTIVITIES
1. Review (10 minutes)
2. Icebreaker (5 minutes)
3. Why Am I So Tired?
(40 minutes)
4. What Should I Eat?
(40 minutes)
5. Wrap Up (10 minutes)




\section{Review}

(10 MINUTES)

Say:

Welcome to today's session. First we are going to review what we learned last week.

\section{Action:}

Repeat the "health, unhealthy, not sure" exercise with the girls. Get the labels: healthy, unhealthy, not sure and stick them on the wall or place on the ground. Place food picture cards in a grocery bagwall or place on the ground. Place food picture cards in a grocery bag.

Hold up one picture at a time of any food from the grocery bag and ask the girls to tell you where it should be placed. Allow discussion if the girls don't agree on the label where the food should go. Continue this process until you have sizeable numbers of food picture cards under each of the labels or headings.

\section{A $1 k$ :}

Ask the girls why it is important to eat nutritionally balanced meals.

X) Wait for a few replies.

\section{Action:}

Facilitate a brief discussion about key points covered in the last session.

Optional: Throw a ball of paper around to encourage participation Fill in any key points missed.

\section{leclereaker: To Whom To}

\author{
(5 MINUTES)
}

Explain:

Now that we have reviewed last week's session, we are going to discuss a new topic-starting by singing a short song. We shall sing the song in parts, starting with a practice round

\section{Action:}

굴 Divide the girls into three groups. Ask group 1 to say "to...to...to...to" repeatedly. Ask group 2 to say "to whom to...to whom to...to whom to...", again repeatedly. Ask group 3 to say "to whom does it belong to...to whom does it belong to...to whom does it belong to..." also repeatedly. Instruct group 1 to start saying their part; let group 2 join in but saying their own part and lastly group 3. Ultimately the three groups get to say their lines simultaneously while gaining momentum in speed and increased volume. The three groups must synchronize and merge as one song.

Allow the girls to repeat the song two or three times.

Ask:

At the very end, ask "to whom does it belong to?" and instruct all the girls to reply "US!!!"

\section{Explain:}

3 The point of this rhythm is to bring our attention to the next topic we will discuss which is very important to us: anaemia.

Even though we might be saying somewhat different things in the song, there is a point at which we meet, working together as a team. Just like with anaemia, we need to work together as a team to find solutions to the problem that affects adolescent girls like us. 


\section{activity 1}

\section{WHY AM I SO TIRED?}

(40 MINUTES)

\section{Explain:}

In this activity we are going to learn about anaemia; a health problem that affects many people, especially adolescents' girls.

\section{Ask:}

Does anyone know what anaemia means?

(x) Wait for a few replies.

\section{Explain:}

Anaemia is a health condition that occurs when the blood does not have enough of one very important nutrient we get from food called iron. When you don't have enough iron in your blood, you are anaemic. Adolescent girls can become anaemic because they don't eat enough of the right kinds of food and because of their menses. When girls have their menses, the amount of iron in their blood can drop through blood loss.
When you are anaemic and have too little iron in your blood, you can feel very weak and tired. You can also feel dizzy from timeto-time. You may also have pale palms, feel breathless, experience headaches and may be too weak to do physical work.

\section{Ation}

Ask for two volunteers to do a role play.

Call the volunteers aside to give them instructions about the role play and a copy of the case scenario "Why Am I So Tired?”, found on page 18.

The scene will be two friends; Chanetsa and Chileshe who bump into each other at the market.

Chanetsa shares with Chileshe about how she has been feeling lately. Ask Chanetsa to act out the different symptoms she is feeling.

Instruct Chileshe to be the friend who listens and asks questions about her friend's health and advises her on what to do.
Emphasize that Chileshe asks Chanetsa what she is eating to establish that she is NOT receiving enough foods with iron.

Give a signal to start the role play.

The scene ends when Chileshe advises Chanetsa to see a health worker about her symptoms and eat good food sources of iron such as beef, pork, chicken, fish, eggs, beans, groundnuts, and dark green leafy vegetables (spinach, bondwe, sweet potato leaves, chibwabwa).

Ask:

How do you feel about what you saw in the role play?

(x) Wait for a few replies and give concluding remarks.

\section{Explain:}

5 Emphasize the role of right food choices in preventing anaemia. 


\section{Case scenaria: Why am / sa tised?}

Chanetsa: Hi, How are you Chileshe?

Chileshe: I am fine. How are you?

Chanetsa: I am fine, sort of..

Chileshe: What do you mean sort of?

Chanetsa: I am not sick but I am always feeling tired and weak.

Chileshe: When did you start feeling like that?

Chanetsa: Oh since about three months ago.

Chileshe: I am sorry about that. But tell me how are you feeling exactly.

Chanetsa: In addition to feeling weak and tired all the time, I also feel dizzy from time to time. Often times I feel sleepy.

Chileshe: Aah...tell me more.

Chanetsa: I also have severe headaches. I experience fast heartbeats and breathlessness especially when climbing stairs.
Chileshe: Let me see your palms and nail beds.

Chanetsa: [shows Chileshe her palms and nail beds]

Chileshe: Oh my....your palms and nail beds look rather pale (asks to look at the eyes too). Your eyes look pale as well. I think you may have anaemia.

Chanetsa: So what should I do? Why do I have anaemia?

Chileshe: It seems to me that you are NOT receiving foods that are rich in iron. You should start eating good food sources of iron such as red meat (beef) pork, eggs, poultry (chicken), fish, legumes (beans and groundnuts), dark green leafy vegetables (spinach, bondwe, sweet potato leaves, chibwabwa).

Equally important, you should go to the clinic and see the doctor.

End of scene 


\section{activity 2}

\section{WHAT SHOULD I EAT?}

\author{
(40 MINUTES)
}

\section{Explain:}

In this activity we learn about how to prevent anaemia by making the right food choices.

\section{Say:}

In order to prevent anaemia we have to eat food with enough iron.

\section{Explain:}

Blood has enough iron by eating good food with lots of iron such as beef, pork, chicken, fish, eggs, beans, groundnuts, and dark green leafy vegetables (spinach, bondwe, sweet potato leaves, chibwabwa).

\section{Action:}

Divide the girls into 2 groups and give each group a deck of selected food pic ture cards.

Ask each group to arrange all food cards into piles of food from animals and food from plants. When they are finished the piles should look like this:
Food from Animals: beef, pork, chicken, fish, eggs.

Foods from Plants: beans and groundnuts, spinach, bondwe, sweet potato leaves, chibwabwa.

\section{Explain:}

t is important to eat foods that have lots of iron in them at every meal. Eating plenty of dark green leafy vegetables in addition to eating fruits after meals can give you enough iron to keep you strong and healthy. You can also occasionally eat a small amount of meat, fish or eggs added to foods such as beans.

\section{Wrap $U_{r}$}

(10 MINUTES)

\section{Action:}

Ask the girls to summarize what they have learnt. Fill in any key points missed.

Key Message: Adolescents need to make healthy food choices to prevent anaemia. This includes eating foods with lots of iron at every meal, including dark green leafy vegetables, beans, fruits, meat and fish.

Ask for final questions or comments.

\section{Explain:}

Remind the girls where and when the next meeting will take place and the topics to be discussed.

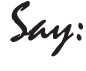

Say:

For the 10-14 year olds: This is the last session in the curriculum. I hope you enjoyed the lessons on nutrition!

For the 15-19 year old girls: We will continue with the topic of nutrition for pregnant adolescents in our meeting next week.

Thank you all for coming today! 


\section{4) Nutrition for Pregnant Adolescents*}

This session discusses the importance of nutrition and other issues surrounding adolescent pregnancy.

FACILITATORS' NOTES: Sufficient energy is a primary dietary requirement of pregnancy. If energy needs are not met, available protein, vitamins and minerals cannot be used effectively for various metabolic functions. Energy requirements are greater for pregnant adolescents than their non-pregnant peers.

OBJECTIVES
By the end of this session, participants
will:
- Explain the importance of good
nutrition in pregnancy
- Explain the factors influencing
nutritional needs of pregnant
adolescents
- Outline eating behaviours and their
implications in pregnant adolescents
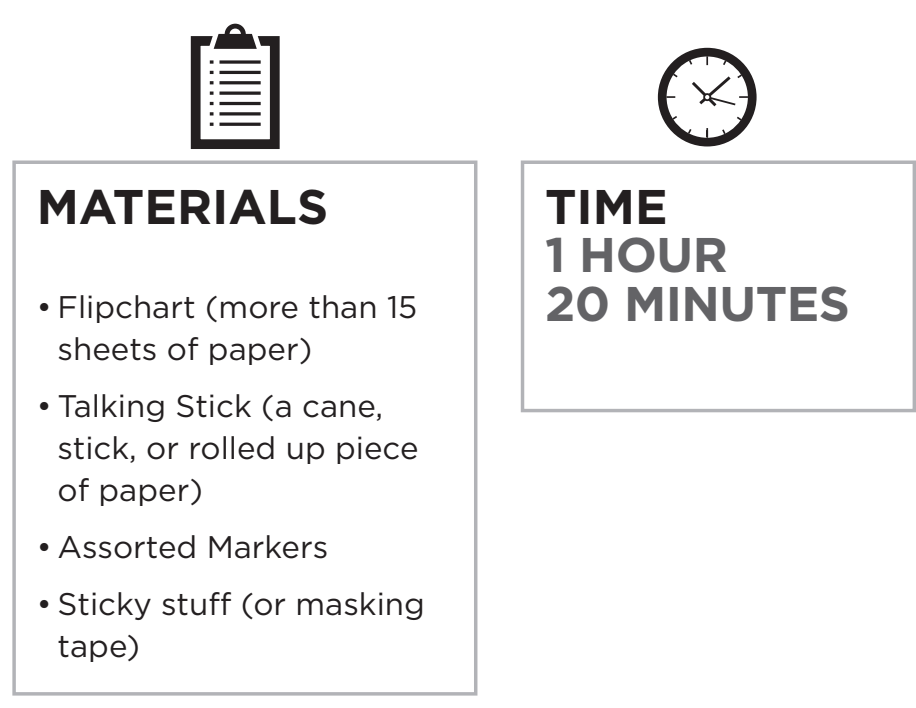

ACTIVITIES
1. Icebreaker (5 minutes)
2. Review (10 minutes)
3. Food and Nutrient Needs in
Pregnancy (30 minutes)
4. Common Eating Behaviours
in Pregnant Adolescents
(25 minutes)
5. Wrap Up (10 minutes)




\section{Kcelreaker: The Ship I1 Sinking}

(5 MINUTES)

\section{Explain:}

5 We are going to play a game called "The ship is sinking". Please all get in a circle. When I say "the ship is sinking" everyone should reply "the ship is sinking". When I say "get into groups of 5" for example, you need to quickly move and get into a group with 4 other friends to form a life raft of 5 people and be saved from the sinking ship. If you find yourself in a group less than the number stated then you are out of the game. We will do a practice round first and then we will play the game.

\section{Action:}

Conduct a practice round by shouting "the ship is sinking" at least two times, with the girls responding, "the ship is sinking!" Then shout out "get into groups of three!". When the girls have followed the instructions and grouped themselves in threes; ask them to form a large circle again. Begin again by shouting, "the ship is sinking" and the girls responding, "the ship is sinking!" Then shout out another number and the girls should form groups of that number. Any girls not in groups or in groups with the wrong number are out of the game.

Continue playing the game up to 5 minutes or until most of the girls are out of the game.

\section{Review}

(10 MINUTES)

Ask:

5 Ask the girls to state what they can remember from the session on anaemia.

\section{Action:}

Throw a ball of paper to any girl to signal that she should give an answer to encourage participation.

Ask:

What can you remember from our last session on anaemia?

Say:

Mention a few key messages covered in the session on anaemia. 


\title{
activity 1
}

\section{FOOD AND NUTRIENT NEEDS IN PREGNANCY}

\author{
(3O MINUTES)
}

\section{Explain:}

We are now going to discuss food and nutrient needs in adolescent pregnancy. Remember that nutrients are the parts of food that are good for us, including protein, vitamins, minerals and carbohydrates.

\section{Ask:}

What do you think are the food and nutrition needs for pregnant adolescents?

Wait for a few replies

\section{Explain:}

Getting enough of the right kinds of foods is important during pregnancy so that girls have enough energy and nutrients so that the baby grows nicely. This is true for all women, but adolescent girls need more nutrients because they are still growing as well. To get enough energy, protein, vitamins and minerals during pregnancy requires that the adolescent girls eat more and the right kinds of foods.

Getting enough iron is of special concern in pregnancy. This is because the need for iron increases in pregnancy due to the food and nutritional needs of the adolescent girl and the baby. The body's need for iron during pregnancy increases as the pregnancy goes on. When an adolescent girl does not have enough iron, anaemia develops. Not having enough iron during the first 6 months of pregnancy can be harmful to the mother and the baby. It can lead to early delivery of the baby or the baby being born at a low birth weight.

\section{Action}

Facilitate a discussion using the food pyramid to remind the girls of the key messages on healthy food choices.

Say:

$\bigcirc$ Like we discussed before, healthy food choices are very important for pregnant adolescents. Remember to increase the amounts and kinds of food so that both the mother and baby grow strong and healthy.

\section{Action:}

Divide the girls into 3 groups. Give them decks of food picture cards. Ask them to identify foods which are good for pregnant adolescents. Allow them five minutes to complete the task then ask them to return as a group and share their responses, giving reasons for the choices. Ask the other girls whether they agree or disagree and give reasons for their answer.
Ask:

5 What are the key health care needs for pregnant adolescents?

(x) Wait for a few replies.

\section{Explain:}

It is best for pregnant adolescents to start attending ante-natal care (ANC) at the health facility as soon as they know that they are pregnant. At the health facility they will be provided with the necessary health care, information, and will be given iron and folic acid tablets. Folic acid, like iron, is another very important nutrient for pregnant girls. At the health facility girls will also learn more about food and nutrition to help both themselves and the baby. 


\section{activity 2}

\section{COMMON EATING BEHAVIOURS IN PREGNANT ADOLESCENTS}

\section{(3O MINUTES)}

\section{Action:}

If Ask for two volunteers to play the role of Jelita, a pregnant adolescent and Chilinda her friend. Call them aside for a briefing on the role play. Give them their roles in the play as follows:

Jelita: Jelita shares her experiences with Chilinda saying, "Lately I have been feeling sickly and weak. I often don't eat as I don't want to grow big so that people will see that I am pregnant. Instead I snack on crisps, Fanta and bubble gum. I spend the day at the market where I keep myself too busy and eat a lot of chips".

Chilinda: Chilinda is to listen and give good advice about healthy eating to her friend Jelita based on what she has learned about food and nutrition.

\section{Explain:}

In this activity we are going to talk about common eating behaviours in pregnant adolescents.

\section{Action:}

When they are ready ask both Jelita and Chilinda to come forward and role play. Ask the rest of the girls to be attentive to the role play. At the end of the role play, ask the girls, "What did you see and learn from the role play? Did Chilinda help her friend improve her nutrition?"

\section{Explain:}

5 In the role play we heard that Jelita was pregnant and skipping meals, preferring to snack on foods high in fat or sugar without little nutritional value. Jelita was too busy to make good food and ate a lot of fast food. Typical of adolescents, Jelita lacked a stable supply of healthy foods and perhaps had limited food preparation skills and facilities.

Ask:

What are some of the ways that Chilinda tried to help her friend Jelita? What kinds of good advice about healthy eating did she give? Is there anything she missed?

\& Wait for a few replies.

Explain:

Chilanda tried to teach her friend that she needs to eat enough of and the right kinds of food at every meal. She points out that pregnant adolescents need to eat healthy because they and the baby are growing. The pregnancy places extra needs on the adolescent's body. To eat the right way, Jelita needs to get food from different food groups, making sure to eat staple, GO, GROW and GLOW foods to get enough nutrients. Also, Jelita needs to know that if she doesn't eat enough iron she may become aneamic which is a danger to both the girl and her baby. If Jelita is losing weight or feeling tired all the time, she should go to the clinic.

\section{Wrap $U_{\text {r }}$}

(10 MINUTES)

\section{Action:}

Ask girls to say what they have learnt in today's session. Fill in any key points missed.

Pregnant adolescents have increased nutrient needs to allow for growth and development for both the baby and the mother. Not getting enough food and the right kinds of food can be dangerous for both the girl and her baby.

Ask for final questions or comments. Remind the girls where and when the next meeting will take place and what topics will be discussed.

Thank you all for coming today. Next week we will talk about how to feed infants and young children 


\section{5) Infant Feeding from Birth through 6 Months*}

This session discusses the role and benefits of breastfeeding. It further explains the practice of breastfeeding early after birth as well as the need to breastfeed newborns exclusively until 6 months.

BBJECTIVES
By the end of this session, participants
will:
- Discuss the role of breastfeeding in
child survival
- List the benefits of breastfeeding
- Discuss the importance of early
initiation of breastfeeding
- List the benefits of exclusive
breastfeeding

MATERIALS
- Flipchart (more than 15
sheets of paper)
- Talking Stick (a cane,
stick, or rolled up piece
of paper)
- Assorted Markers
- Sticky stuff (or masking
tape)
- Picture of a
breastfeeding mother

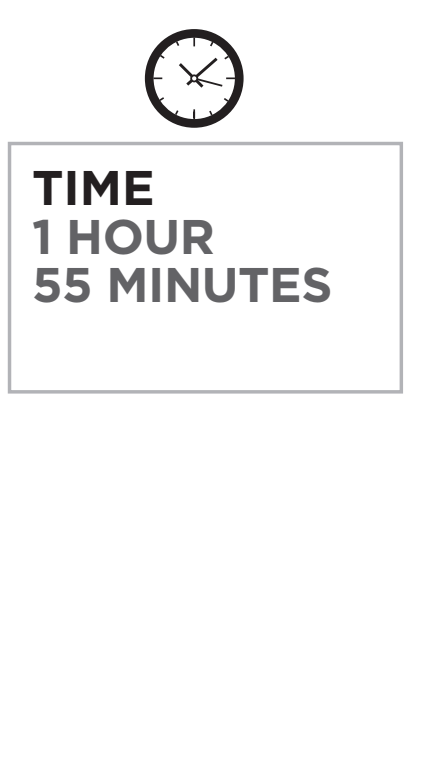

ACTIVITIES
1. Review (15 minutes)
2. Breastfeeding ( 25 minutes)
3. Early Initiation of Breast-
feeding ( 40 minutes)
4. Exclusive Breastfeeding
until 6 Months of Age
(25 minutes)
5. Wrap Up (10 minutes)




\section{Review}

(15 MINUTES)

\section{Explain:}

We are going to complete a quick review of last week's session on nutrition for pregnant adolescents.

\section{Action:}

Divide the girls into 4 groups and provide them with a grocery bag with the food cards. Ask each group to review the cards and identify which foods pregnant adolescents should eat more of. Display the food pyramid and have the girls organize the foods according to the food pyramid. Walk around and help the girls with their identification.

After 5 minutes bring the group back together to identify where foods should go on the pyramid and which foods a pregnant adolescent should eat.

Remind the girls of the importance of eating healthy foods.

\section{activity 1}

\section{BREASTFEEDING}

(25 MINUTES)

\section{Explain:}

$\bigcirc$ In this activity we are going to talk about the importance of breastfeeding.

Say:

5 Close your eyes and imagine a mother breastfeeding her baby.

W) Wait for a minute.

Ask:

5 What did the image in your head look like?

W Wait for a few replies.

\section{Explain:}

A breastfeeding mother gives her baby the best food possible at the start of life. Breast milk is the baby's perfect first food; having all the necessary nutrients including energy, protein, vitamins and minerals. Breastfeeding is important for child health, an expression of love, care, protection and a way of nurturing the young. It is an extension of maternal protection from the shelter of the mother's womb to the outside world. Breastfed babies are healthier; achieving the best growth and development compared to those fed with milk formula.

Breastfeeding helps development of the motherchild bonding. It protects the mothers' health, costs less than milk formula and provides perfect nutrients required for the baby's growth and development. Breast milk is easily digested by the baby, it is clean and always ready to use and protects the baby against common infections. It helps the mother's uterus to return to its previous size; it helps to reduce bleeding after delivery and prevents anaemia. Breastfeeding also reduces the risk of ovarian and breast cancer in the mother. Colostrum, the very first milk to come from the breast (creamy and slimy) contains important nutrients that help fight diseases. For some mothers, their breast milk doesn't come in or it is not enough for the baby. In those cases you need to seek guidance from a health care provider at the clinic.

Breastfeeding is also very important for HIV exposed babies. HIV positive mothers should go for ante-natal care at the health facility. There they will receive drugs that can prevent their baby from getting HIV. They will also learn about breastfeeding and HIV.

\section{Action:}

Divide the girls into 2 groups. Ask the groups to discuss the question "what are the benefits of breastfeeding?" Go around to the groups and provide guidance. Ask the groups to keep track of the key points raised. Bring everyone back together and ask each group to present what they discussed in their groups. After both groups have presented, bring up any points missed. 


\title{
activity 2
}

\section{EARLY INITIATION OF BREASTFEEDING}

\author{
(40 MINUTES)
}

\section{Explain:}

We are now going to talk about the importance of starting breastfeeding very soon

Ask: after birth

When should a mother start breastfeeding her baby?

(x) Wait for a few replies

\section{Explain:}

A mother should start breastfeeding her baby as soon as possible within the first hour of giving birth. The very first breast milk (colostrum) is rich in important nutrients for early growth and preventing infections in the baby. The amount of colostrum is small, but it is exactly what a baby needs at this time. The colostrum starts the newborn's sucking behaviour. This action will help the mother produce more breast milk. Breastfeeding encourages bonding between the mother and baby resulting in better latch. Breastfeeding helps to maintain the baby's body temperature by providing warmth to the baby, which is very important for a newborn. Starting breastfeeding early helps the mother to make more milk.

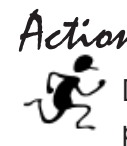

Demonstrate how the baby should be placed to the breast immediately after birth. If possible, use a doll to demonstrate.

\section{Say:}

To start breastfeeding as soon as possible after birth, it is best that the mother and baby stay in the same room and sleep in the same bed. This is referred to as rooming-in and bedding-in so that the mother learns early when the baby is hungry.

\section{Explain:}

For the best suckling, the baby should be positioned and attached to the breast properly.

\section{Action:}

늘 Demonstrate proper positioning and attachment. Arrange a low seat. If there are mothers in the group, ask for a volunteer mother and baby to come forward. Let the mother sit in a comfortable and relaxed position. Show the mother how to hold the baby by observing the 4 key points for positioning and ask the other girls to observe. If there are no mothers in the group or no one is comfortable coming forward, the mentor should use a baby doll to demonstrate the position.

\section{Explain:}

The 4 key points for positioning are that:

1. The baby's head and body must be in line;

2. Baby is held close to the mother's body

3. The baby's whole body must be supported (not just the neck and shoulders). The mothers hand and palm should hold the baby's whole body - head, shoulder, back and buttocks. The baby's head should rest in the crook of the arm and the baby should approach the breast nose opposite the nipple.

4. The baby approaches the breast nose to nipple. 


\section{activity 2 (continued)}

\section{Explain:}

Support the breast as follows: the fingers

must be placed against the chest wall below

the breast. Support the breast with the first

finger, the thumb must be above the breast.

The fingers should not be too near the nipple.

\section{SUPPORTING THE BREAST IN DIFFERENT POSITIONS}

\section{A mother holding her baby In} underarm position

Useful for:

- Twins

-When having difficulty attaching the baby

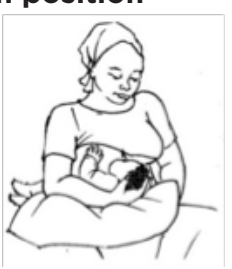

2. A mother holding her baby with the arm opposite the breast

Useful for:

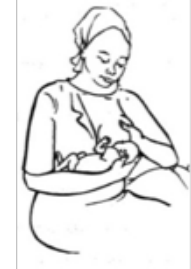

- very small babies

- sick babies
3. A mother breastfeeding her baby lying down

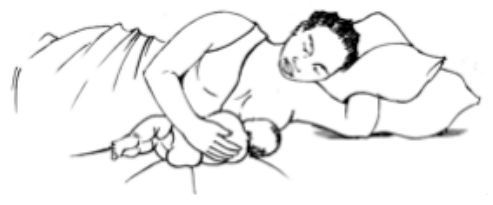

Action:

2 Demonstrate how to support the

breast in different positions as shown in the diagram.

\section{Explain:}

$\bigcirc$ Look and listen for the baby taking slow deep sucks. This is an important sign that the baby is suckling well and getting enough breast milk. If a baby takes slow, deep, sucks then she or he is probably well attached.

If the baby is taking quick shallow sucks all the time, this is a sign that the baby is not suckling well. If the baby is making smacking sounds as $\mathrm{s} /$ he sucks this is a sign that $\mathrm{s} /$ he is not well attached. It is important that the baby releases the breast after the feed and looks sleepy and satisfied. If a mother takes the baby off the breast before s/he has finished, e.g. if s/he pauses between sucks, s/he may not get enough hind milk. Hind milk is the milk that comes out after some time of breastfeeding. It is thick and creamy because it contains a lot of fat, which is needed by a newborn.

A baby that does not breastfeed well does not gain enough weight. The baby's urine may be very little, dark yellow in colour and not come often. 


\title{
activity 3
}

\section{EXCLUSIVE BREASTFEEDING UNTIL SIX MONTHS OF AGE}

\author{
(25 MINUTES)
}

Explain:

In this activity we are going to talk about exclusive breastfeeding until six months of age-that is, not giving the baby anything else to drink or eat except breast milk.

Ask:

Does a baby need more food than just breast milk before they are six months of age? Why or why not?

Wait for a few replies.

\section{Explain:}

Exclusive breastfeeding is the act of giving an infant only breast milk for six months and no other liquids or solids, not even water. orange juice or vitamin and mineral syrups. Unless instructed by a health care provider breast milk contains all the food and nutrients that the baby needs through the first six months of life. Babies should be fed as often as they are hungry.

There are many benefits to exclusive breastfeeding, including better survival, decreased illness and improved growth. Exclusive breastfeeding during the first six months can be life-saving, by preventing infections like diarrhea, pneumonia and sudden death Exclusive breastfeeding helps overcome low birth weights (LBW) and reduces slow growth.

Some mothers cannot produce enough milk for their babies from their breasts. In such cases, a health care provider will talk about the best ways of getting the baby the food she needs, including milk formula.

Ask:

What are the dangers of giving the baby solid food or fluid before the age of six months?

Wait for a few replies.

\section{Explain:}

$\int$ The baby is more likely to have diarrhoea and get respiratory and other infections. The baby may get too little breast milk and become malnourished, which means that she or he doesn't get enough of the needed nutrients. Also the baby is more likely to have allergic conditions such as skin rashes and possibly asthma, which is difficulty breathing. There is a risk of developing some long-term diseases such as diabetes, a condition in which the body has a hard time using sugar. Breastfeeding can also help mothers not get pregnant soon after the child's birth, although family planning appropriate for breastfeeding mothers should be used after childbirth to ensure the prevention of pregnancy.
Action:

Ask for two volunteers to do a role play. Pull them aside to instruct them in their roles. One girl will be a mother with a healthy six-month-old baby; the other girl will be a mother with a sickly threemonth-old baby. Have the mother with the sickly baby describe the baby's symptoms of having diarrhea, getting sick, having skin rashes, and is not growing very quickly.

The mother of the healthy baby will ask questions about the baby's health and ask about what the mother of the sickly baby feeds her. The mother will describe how she feeds the baby breast milk,

formula, cereal, water, and other foods to promote weight gain and growth.

The scene will end with the mother of the healthy baby encouraging her friend to exclusively breastfeed her baby until the baby is six months old to improve her health and recommend the mother take the baby to the health centre to make sure nothing else is wrong. 


\section{Wrap Ur}

(10 MINUTES)

\section{Action:}

if Ask the girls to summarize what they have learnt. Fill in any key points they miss.

Provide the key messages on feeding babies from birth through 6 months.

\section{Action:}

iै Ask for final questions or comments. Re-

mind the girls where and when the next

meeting will take place and the topic to be discussed.

Thank you all for coming today. I look forward to seeing you next week. 


\section{6) Young Child Feeding and Growth Monitoring*}

This session provides guidance on how to feed children after 6 months of age. It also provides an overview of child growth monitoring using the children's Under-Five Clinic Card.

OBJECTIVES
By the end of this session, participants
will:
- Discuss how to feed a baby after
6 months of age
- List appropriate foods for babies
after 6 months
- Discuss the importance of growth
monitoring
- Review the children's under-five
clinic card
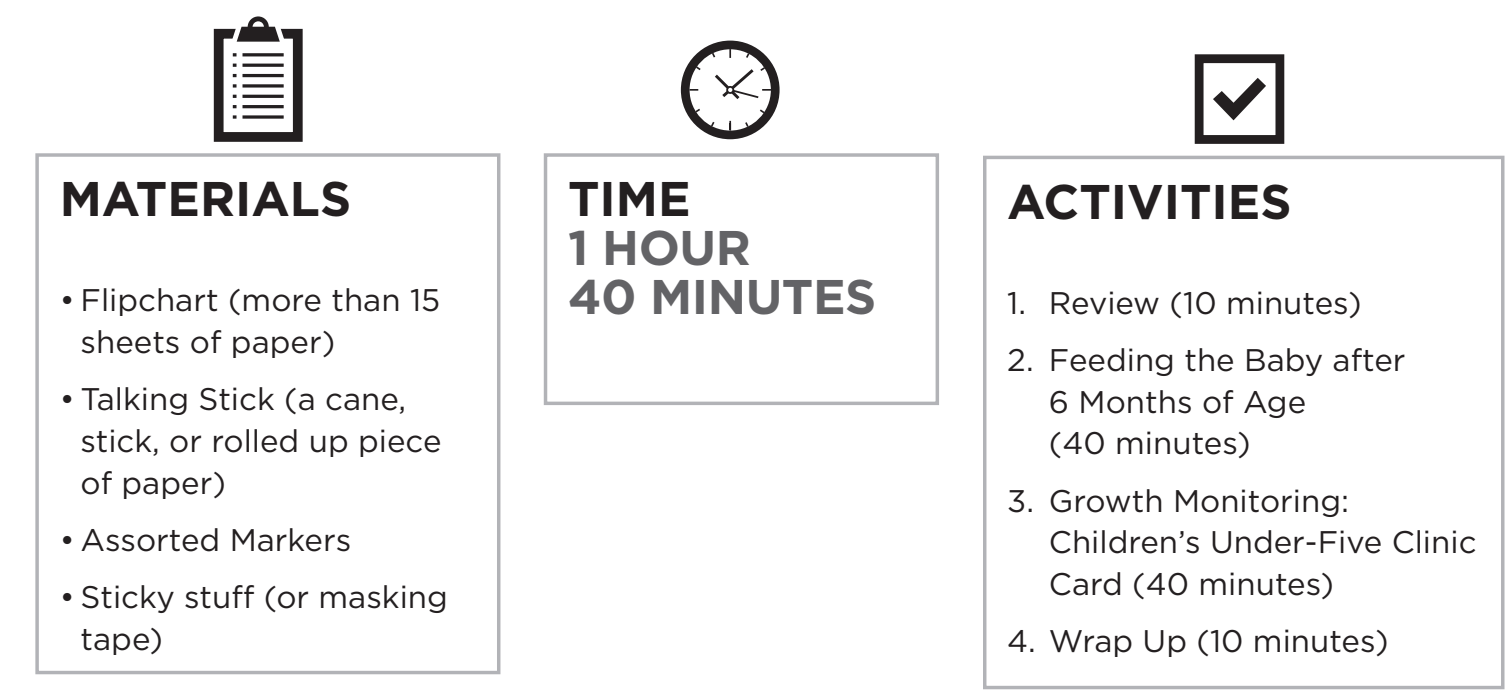


\section{Review}

(10 MINUTES)

\section{Explain:}

We are going to complete a quick review of last week's session on infant feeding from birth through six months.

Ask:

Ask the girls to share what they can remember from the last session.

\section{Atrean}

Throw a ball of paper to any girl to signal that she should give an answer to encourage participation.

Remind the girls of the importance of early initiation and exclusive breastfeeding. 


\section{activity 1}

\section{FEEDING THE BABY AFTER SIX MONTHS OF AGE}

\section{(40 MINUTES)}

Explain:

In this activity we are going to talk about how to feed the baby after six months of age.

Ask:

How do you think babies should be fed after six months of age.

Q Wait for a few replies.

\section{Explain:}

After six months of age, the baby should continue to breastfeed and be given semisolid or solid foods and other fluids. All children need a variety of foods, including staples, animal source foods, vegetables and fruits, high-energy food and enriched foods (GO, GROW and GLOW foods). Solid foods should be enough, safe and nutritious in order to reduce the risk of malnutrition or not getting enough of the right nutrients. To ensure that children get all the nutrients they need at each meal, select different foods from the different food groups. As children get older, increase the variety and quantity of foods. Continued breastfeeding is recommended, even up to the age of two years. After six months of age, the child should be breastfed and eat three meals of solid food and fluids per day.

Ask:

How should solid foods be prepared for a baby?

(x) Wait for a few replies.

\section{Explain:}

The stomach of a young child is small. At eight months of age the stomach can hold only very small amounts at one time. Thin foods and liquids fill the stomach quickly before the energy need is met so they need to be fed small amounts of food more frequently. Thickness of foods makes a big difference to how well that food meets the young child's energy and nutrient needs.

\section{Action:}

Show this image below of porridges of different consistencies. Ask the girls which of the two porridges is best to feed a baby.

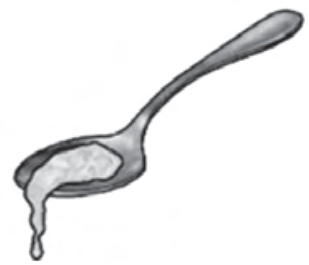

Too thin

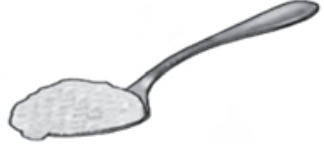

Good thickness 


\section{activity 1 (continued)}

\section{Explain:}

Foods that are thick help to fill the energy and nutrient needs of the baby better.

Key points to remember about feeding babies are as follows:

1. When the baby reaches six months, continue breastfeeding on demand, both night and day. Breast milk continues to be an important part of the baby's diet until the baby is 2 years.

2. When feeding a baby always give breast milk first before giving foods.

3. When the baby first starts to eat, give 1 or 2 tablespoons of soft food three times per day every day. Gradually increase the frequency, amount, thickness and variety of foods. Foods of a thick consistency help to fill the needs of the baby better.

4. Make the baby's porridge and mashed foods better with breast milk, beans, mashed groundnuts, fruits and vegetables. Start with animal source foods (finely chopped fish, eggs, meat) as early and as often as possible.
5. Feed children mashed fruits and vegetables such as ripe banana, pawpaw, avocado and pumpkin as often as possible.

6. Avoid giving a baby tea, coffee, soft drinks and sugary or coloured drinks.

7. Always feed the baby using a clean open cup.

8. During illness give the baby small frequent meals and more fluids, including breast milk or other liquid. Encourage the baby to eat a variety of (his or her) favourite soft foods.

9. After illness feed the baby more food and more often than usual for at least 2 weeks to help the baby recover quickly.
Ask:

What foods should not be fed to children?

W) Wait for a few replies.

Explain:

$\int$ Do not feed infants drinks with sugar, soda or soft drinks (fizzy drinks), and do not let them eat sweeties.

To meet the nutritional needs ensure that the complementary feeds be:

- $\quad$ Timely - introduced when the need for energy and nutrients is more than what can be provided through only and frequent breastfeeding.

- $\quad$ Adequate - provide enough energy, protein and nutrients to meet a growing child's nutritional needs.

- $\quad$ Safe - stored safely and prepared and fed with clean hands using clean utensils and not bottles and teats.

- Responsive - given in response to a child's signals of hunger and that meal frequency and feeding methods are suitable for the child's age. 


\section{activity 2}

\section{GROWTH MONITORING: CHILDREN'S UNDER-FIVE CLINIC CARD}

\section{(40 MINUTES)}

Explain:

In this activity we are going to talk about growth monitoring and how to use the children's under-five clinic card to chart growth.

\section{Action:}

Show the group a copy of the Under-Five Children's Clinic Card. Pass it around for everyone to look at.

\section{Ask:}

Has anyone seen this card before? If yes, do you know what is used for? And why it is important?

冈 Wait for a few replies

\section{Explain:}

This is the Under-Five Clinic Card given out at clinics in Zambia for newborn children. This card is given to parents when they first bring their babies to the clinic so they can keep important information about the health of their child as he or she grows.
Today, we are going to look at the growth chart for children or the child's weight-forage (point to "Weight-for-age" chart"). The growth chart helps parents see how their child grows over the first five years. In the first five years, parents should bring their children under the age of five to the clinic every month to measure their weight. The clinic staff will weigh the child and write down the child's weight for that month on this chart.

Ask:

Why is the weight of a baby important?

(x) Wait for a few replies

\section{Explain:}

3 Weight is very important because it helps to show how well a baby is growing. Babies must get enough food to grow properly. If they are getting too little food, or not the right food, it can affect their health and welfare in many ways.
- Not getting enough food can slow physical growth and the child's ability and strength to use his or her arms and legs for crawling and walking.

o Good nutrition helps the body's ability to fight sickness and disease; proper nutrition keeps the body healthy.

o Good nutrition improves child learning and attention, even their ability to learn later in life.

Now, let's take a closer look at how the growth chart works:

o The age of the child can be seen on the bottom, from birth to up to 5 years of the child's life. This time is also listed in months.

o On the left of the growth chart, the baby's weight is measured in $\mathrm{kgs}$, from $\mathrm{O}$ at the bottom to $30 \mathrm{~kg}$ at the very top.

Ask:

2 About how much does a baby typically weigh when they are born?

(x) Wait for a few replies. 


\section{activity 2 (continued)}

\section{Explain:}

In Zambia, a baby will typically weigh about $2.5 \mathrm{kgs}$ when they are born. Their weight may be a little more or a little less than this weight.

Their birth weight would be added to the growth chart at the very edge of the chart.

\section{Action: \\ Point out where birth weight is indicated.}

\section{Explain:}

3 Now, let's take a closer look at how the growth chart works:

o When you weigh your baby at the clinic, health centre staff will enter the baby's weight as a dot on the chart each month. The dots will be connected with a line to see how the child is growing.

\section{Action:}

Foint to "Good", "Danger Sign" and "Very Dangerous" lines at the top of the chart and read:

$\checkmark$ If the line goes up every month (show the increasing line, marked 'GOOD' on the chart), then that means that the child is growing nicely.

$\checkmark$ If the line stays the same (show the line that is straight, marked 'DANGER SIGN' on the chart), the child may not be getting the food and nutrition needed. The parents must provide more nutritious food for the child. The parents must provide more nutritious food for the baby and ask the clinic staff for suggestions of the best foods.

$\checkmark$ If the line has gone down (show the decreasing line, marked 'VERY DANGEROUS' on the chart), then the child may be ill and need extra care from the clinic staff and parents.

o The GREEN line in the middle of the chart (point to the green line) shows how a usual child grows in the first five years of life. Ideally, a child should grow each month along or above the green line.

- Now look at the RED line below the green line (point to the red line). When a child's weight is close to the red line, then that child is not getting enough of the food and nutrition needed and the parents should seek assistance on how to add to the child's eating so that he/she starts growing properly.

o Below the red line is a BLACK DOTTED line (point to the black dotted line). If a child's weight falls on, near, or below the dotted line, then the parents should seek help from the clinic, as the baby is very underweight and may require medical attention.
To keep a child growing nicely, the chart also shows the number of meals a child should have during the first five years (point to pictures of breastfeeding woman and bowls of food).

o From birth to six months: the baby should breastfeed exclusively.

o From six months to one year: the baby should breastfeed and should also have 3 meals per day.

o From one to two years: the baby should breastfeed and should also have 3 main meals per day and 2 snacks per day.

o From two to five years: the baby should have 3 main meals per day and 2 snacks per day. 


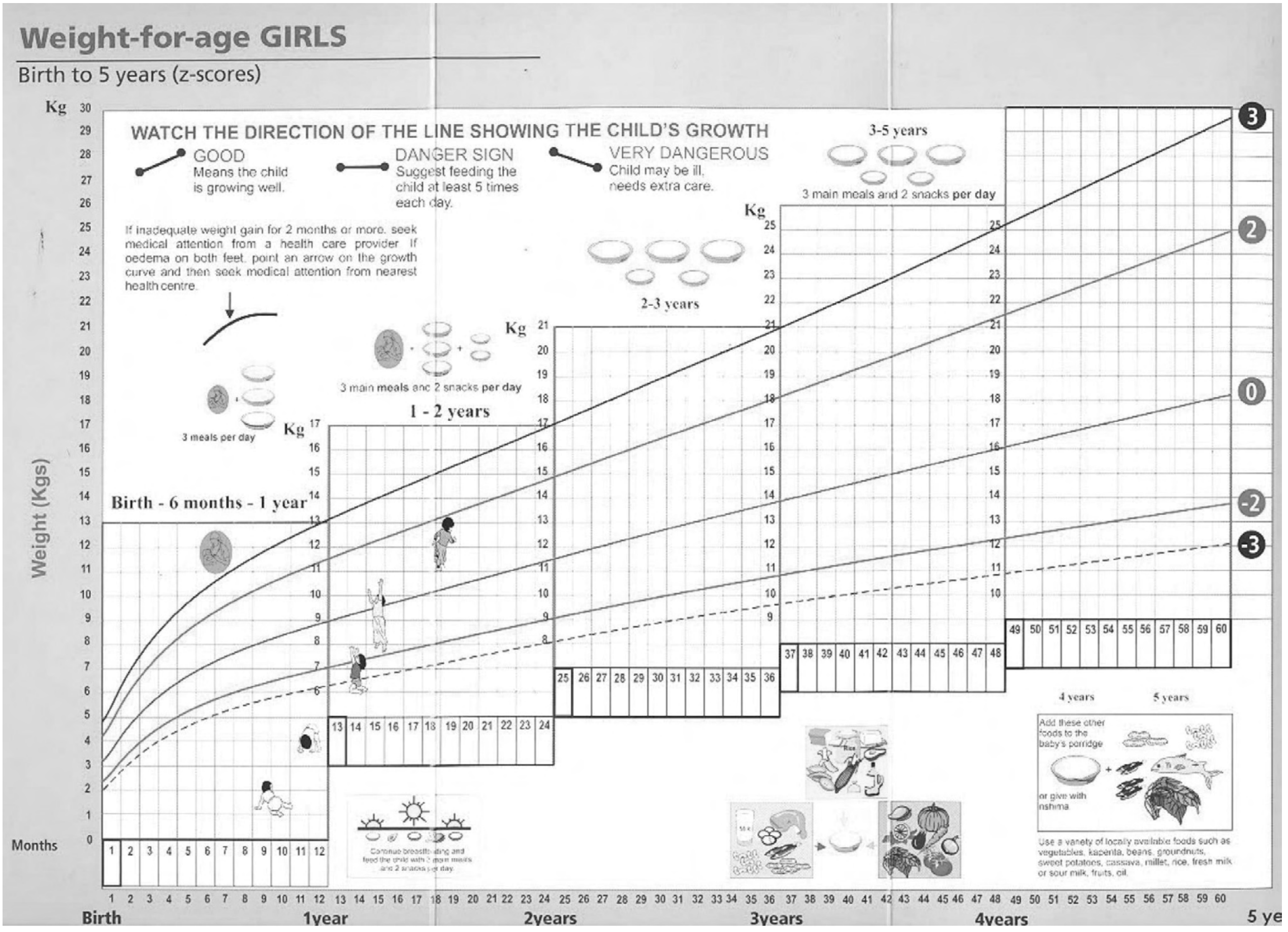




\section{Wrap $U_{r}$}

(10 MINUTES)

\section{Action:}

Ask the girls to summarize what they have learnt. Fill in any key points they miss.

Provide the key messages on complementary feeding

\section{Ask:}

5 How do you feel about what you have learnt about nutrition? What did you like most and why? What did you not like and why?

\section{Antan}

Ask for final questions or comments. Remind the girls where and when the next meeting will take place and the topic to be discussed.

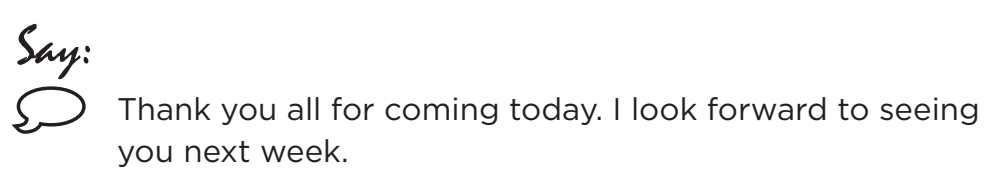
you next week. 


\section{REFERENCES}

All sessions were adapted from the guides and curricula referred to below. Other publications referenced below were used to enhance content of the sessions.

Abstinence Elder, L.K. and Ransom, E.I. 2003. Nutrition of Women and Adolescent Girls: Why It Matters. Washington, D.C.: Population Reference Bureau [PRB], 2003 Jul.

MOH. 2007, Children's Clinic Card Procedures Manual - Zambia.

MOH. 2008. Infant and Young Child Feeding Counseling: An Integrated Course. Trainers Guide.

Montgomery, K.S. 2003. "Improving nutrition in pregnant adolescents: Recommendations for clinical practitioners," Journal of Perinatal Education 12(2): 22-30.

Moon, Ursula. 2010. Vegetables High in Iron \& Vitamin C, www. livestrong.com/article/236274-vitamin-b-rich-foods/

Stang, J. and Story M. 2005. Guidelines for Adolescent Nutrition Services. Minneapolis, MN: Center for Leadership, Education and Training in Maternal and Child Nutrition, Division of Epidemiology and Community Health, School of Public Health, University of Minnesota.

Whitney, E and Rolfes, S.R. 2005. Understanding Nutrition, 10th Edition. Thomson Wadsworth.

WHO. 2008. Adapted Training Course on Child Growth Assessment-WHO Child Growth Standards: Facilitators Guide.

Zambia Demographic Health Survey (ZDHS). 2007. Feeding Practices and Nutritional Status of Women and Children. 

For more information, contact

Population Council - Zambia

Plot 3670 No. 4 Mwaleshi Road

Olympia Park, Lusaka

P/Bag RW 319X, Lusaka 10101, Zambia

Lusaka, Zambia 10101

Tel: +260 211295925

www.popcouncil.org 